\title{
FUNGSIONALISASI HUKUM PIDANA TERHADAP KORPORASI YANG MELAKUKAN PEMBUANGAN LIMBAH B3 (BAHAN BERBAHAYA DAN BERACUN) DI DAERAH ALIRAN SUNGAI CITARUM DIHUBUNGKAN DENGAN ASAS KEADILAN
}

\author{
Gatot Satrio Utomo \\ Program Studi Doktor Ilmu Hukum \\ Pascasarjana Universitas Islam Bandung \\ e-mail: unitsatusubditempat@gmail.com
}

\begin{abstract}
Abstrak : Salah satu contoh dari tindak pidana lingkungan hidup adalah pencemaran air sungai, Daerah Aliran Sungai (DAS) Citarum merupakan salah satu sungai terpanjang. Ironisnya kondisi sungai Citarum saat ini dalam keadaan kritis akibat dari segala faktor yang ada, seperti pencemaran lingkungan hidup yang melibatkan korporasi, sebagai akibat dari aktivitasnya yang berskala besar dalam menjalankan usahanya. Penegakan hukum lingkungan dalam arti yang luas, yaitu meliputi preventif dan represif. Untuk memahami fungsionalisasi penegakan hukum pidana terhadap korporasi yang melakukan pembuangan limbah B3 (bahan berbahaya dan beracun) di daerah aliran sungai Citarum dengan asas keadilan. Untuk memahami penegakan hukum pidana terhadap korporasi yang melakukan pembuangan limbah B3 (bahan berbahaya dan beracun) di daerah aliran sungai Citarum. Metode Pendekatan yang digunakan dalam penelitian ini adalah pendekatan yuridis normatif. Fungsionalisasi hukum pidana dalam rangka pencegahan dan penanggulangan kejahatan umumnya serta kejahatan korporasi yang melakukan pembuangan limbah B3 di daerah aliran sungai Citarum dapat dilakukan beberapa tahap. Tahapan tersebut antara lain tahap formulasi, tahap aplikasi dan tahap eksekusi.
\end{abstract}

Kata Kunci: Fungsionalisasi Hukum Pidana, Pencemaran Sungai Citarum, Korporasi, Asas Keadilan

Abstract : One example of environmental crime is pollution of river water, The Citarum Watershed is one of the longest rivers in the West Java region that has a length of $269 \mathrm{~km}$. Ironically, the current condition of the Citarum River is in a critical condition due to all existing factors, such as liquid waste from environmental pollution involving corporations, as a result of large-scale activities in carrying out their business. Enforcement of environmental law in a broad sense, which includes preventive and repressive measures. To understand the functionalization of criminal law enforcement against corporations that discharge B3 waste (hazardous and toxic materials) in the Citarum watershed with the principle of justice. To understand the enforcement of criminal law against corporations that conduct disposal of B3 waste (hazardous and toxic materials) in the Citarum watershed. Method The approach used in this study is a normative juridical approachFunctionalization of criminal law in the context of the prevention and overcoming of general crimes and corporate crimes that carry out the disposal of B3 waste in the Citarum river basin can be carried out in several stages. These stages include the formulation stage, the application stage and the execution phase.

Keywords: Functionalization of Criminal Law, Pollution of Citarum River, Corporation, Principle of Justice. 


\section{A. PENDAHULUAN}

Fungsionalisasi hukum pidana akan identik dengan operasional atau konkretisasi hukum pidana, yang hakikatnya sama dengan penegakan hukum. Fungsionalisasi ini terdapat tiga tahap kebijakan formulasi sebagai suatu tahap perumusan hukum pidana oleh pihak pembuat perundang-undangan, tahap kebijakan aplikatif sebagai penerapan hukum pidana oleh pihak hukum, tahap kebijakan administratif yaitu tahap pelaksanaan oleh aparat eksekusi hukum. ${ }^{1}$

Penegakan hukum lingkungan harus ditinjau lebih luas kearah penegakan hukum pada umumnya secara makro. Penegakan hukum dapat berjalan dengan baik bergantung dari tiga faktor yang esensial yaitu adanya peraturan perundangundangan yang memadai, peningkatan profesionalisme aparat penegak hukum dan kesadaran hukum masyarakat.

Berdasarkan hal diatas bahwa pada hakikatnya fungsionalisasi hukum pidana merupakan suatu rangkaian dari penegakan hukum pidana. Soedarto memberi arti pada penegakan hukum adalah perhatian dan penggarapan perbuatan-perbuatan yang melawan hukum yang sungguh-sungguh

\footnotetext{
${ }^{1}$ Barda Nawawi Arief, Beberapa Aspek Kebijakan Penegakan Hukum Pidana dan Pengembangan Hukum Pidana, PT. Citra Aditya Bakti, Bandung, 1998, Hlm. 30
}

terjadi (onrecht in actu) maupun perbuatan melawan hukum yang mungkin akan terjadi (onrecht in potenti). ${ }^{2}$

Permasalahan lingkungan hidup adanya perangkat aturan perundangundangan yang mengatur lingkungan hidup secara menyeluruh adalah sangat menunjang penegakan hukum. Selain itu kualitas aparat penegak hukum di antaranya polisi sebagai penyidik/penyelidik, jaksa sebagai penuntut umum dan hakim, kesemuanya harus terus ditingkatkan dan yang tidak kalah pentingnya adalah harus selalu ditingkatkan kesadaran hukum masyarakat akan pentingnya pelestarian lingkungan kehidupan manusia.

Disini hukum tidak hanya dipakai mengukuhkan pola-pola kebiasaan dan tingkah laku yang terdapat dalam masyarakat, melainkan juga untuk mengarahkan kepada tujuan-tujuan yang dikehendaki. Inilah yang disebut sebagai pandangan modern tentang hukum itu yang menjurus kepada penggunaan hukum sebagai suatu instrumen. ${ }^{3}$

Upaya-upaya dalam menanggulangi masalah tersebut harus selalu dilakukan, seperti membuat aturan

\footnotetext{
${ }^{2}$ Sudarto, Kapita Selekta Hukum Pidana, Alumni, Bandung, 1985, Hlm.54

${ }^{3}$ Satjipto Rahardjo, Ilmu Hukum, PT. Citra Aditya Bakti, Bandung, 2005, Hlm. 169
} 
Gatot Satrio Utomo, Fungsionalisasi Hukum Pidana Terhadap Korporasi Yang Melakukan Pembuangan Limbah..

pelaksanaan perundang-undangan berkaitan dengan lingkungan hidup yang telah diatur dalam Undang-Undang Nomor 32 Tahun 2009 tentang Perlindungan dan Pengelolaan Lingkungan Hidup, profesionalisme aparat penegak hukum dalam menangani masalah lingkungan hidup terutama yang berkaitan dengan tindak pidana pencemaran dan perusakan lingkungan hidup. Langkah tersebut merupakan instrumen penting dalam penegakan hukum lingkungan yang dapat dilakukan untuk menekan jumlah pencemaran dan perusakan lingkungan. Kesadaran hukum akan pentingnya masalah lingkungan hidup ini harus selalu ditanamkan bagi semua warga masyarakat karena esensi pelestarian lingkungan tersebut berguna selain untuk diri sendiri juga untuk warga masyarakat dan lebih makro lagi untuk negara.

Hal yang prinsip dalam hukum lingkungan ini adalah adanya persamaan persepsi tentang lingkungan hidup terutama dalam tindak pidana mengenai pencemaran dan perusakan lingkungan hidup. Persamaan persepsi tersebut penting sekali terutama bagi jajaran aparat penegak hukum. Esensinya adalah sama-sama berpandangan bahwa penegakan hukum tersebut untuk menekan jumlah lebih besar pencemaran dan perusakan lingkungan hidup yang akan menghambat jalannya pembangunan serta merugikan masyarakat.

Peningkatan penegakan hukum lingkungan hidup ini perlu sekali setelah berbagai upaya untuk menanggulangi pencemaran dan perusakan lingkungan dilakukan oleh pemerintah. Memang apabila dikaji lebih lanjut, berbagai upaya untuk menanggulangi pencemaran dan perusakan lingkungan, maka sudah seharusnya pada saat sekarang ini hukum perlu dikedepankan dengan cara meningkatkan penegakan hukum. Dengan cara demikian itu fungsi hukum sebagai senjata pamungkas (ultimum remendium) tidak bisa dihindari lagi. ${ }^{4}$

Hukum dasar yang mengatur tentang lingkungan hidup tertuang dalam Pasal 28 h Undang-Undang Dasar Republik Indonesia Tahun 1945, bahwa lingkungan hidup yang baik dan sehat merupakan hak asasi setiap warga negara Indonesia. Kualitas lingkungan hidup yang semakin menurun telah mengancam kelangsungan perikehidupan manusia dan mahluk hidup lainnya sehingga perlu dilakukan perlindungan dan pengelolaan lingkungan hidup yang sungguh-sungguh

\footnotetext{
${ }^{4}$ Muladi dan Barda Nawawi Arif, Teori-teori dan Kebijakan Pidana, Alumni, Bandung, 2005, Hlm. 15
} 
Gatot Satrio Utomo, Fungsionalisasi Hukum Pidana Terhadap Korporasi Yang Melakukan Pembuangan Limbah..

dan konsisten oleh semua pemangku kepentingan. ${ }^{5}$

Formulasi kebijakan tersebut telah dirumuskan dalam Peraturan Presiden Nomor 7 Tahun 2005 tentang Rancangan Pembangunan Jangka Menengah Tahun 2004-2009, penjelasannya dituangkan dalam Bab 23 Tentang Perbaikan Pengelolaan Sumber Daya Alam dan Pelestarian Fungsi Lingkungan Hidup.

Melakukan pengaturan lingkungan telah dibuat berbagai undang-undang dan Peraturan Pemerintah serta peraturanperaturan lainnya. Peraturan khusus mengenai lingkungan hidup adalah Undang-Undang Nomor 32 Tahun 2009 tentang Perlindungan dan Pengelolaan Lingkungan Hidup yang menggantikan Undang-Undang Nomor 23 Tahun 1997 (LN 1997 No. 68) tentang Pengelolaan Lingkungan Hidup yang sebelumnya menggantikan Undang-Undang Nomor 4 Tahun 1982 (LN 1982 No. 12) tentang Ketentuan-Ketentuan Pokok Pengelolaan Lingkungan Hidup. Undang-undang ini merupakan ketentuan paying untuk semua ketentuan peraturan perundang-undangan yang berkenaan dengan lingkungan hidup.

\footnotetext{
${ }^{5}$ Muhammad Erwin, Hukum Lingkungan Dalam Sistem Perlindungan dan Pengelolaan Lingkungan Hidup di Indonesia, PT. Refika Aditama, Bandung, 2015, Hlm. 15
}

Hukum itu sifatnya umum, mengikat semua orang, dan menyamaratakan. Dalam penataan dan penegakan hukum lingkungan, unsur kepastian, unsur kemanfaatan, dan unsur keadilan harus dikompromikan, ketiganya harus mendapat perhatian secara proporsional, sehingga lingkungan yang tercemar dapat dipulihkan kembali. ${ }^{6}$

Penyelesaian kasus lingkungan hidup di Indonesia belum dapat dilakukan secara efektif, karena membutuhkan waktu yang cukup lama dan kurang memberikan kepastian hukum dan keadilan bagi masyarakat, apalagi dalam hal penyelesaian kasus pencemaran lingkungan hidup yang melibatkan korporasi, sebagai akibat dari aktivitasnya yang berskala besar dalam menjalankan usahanya. $^{7}$

Ironisnya kondisi sungai Citarum saat ini dalam keadaan kritis akibat dari segala faktor yang ada, seperti limbah cair dari industri tekstil, limbah rumah tangga, dan limbah peternakan. Sungai Citarum yang berada di salah satu wilayah, yaitu

\footnotetext{
6 Sudikno Mertokusumo, Mengenal Hukum (Suatu Pengantar), Liberty, Yogyakarta, 1999, Hlm. 134-135

${ }^{7}$ Rufinus Hotmaulana Hutauruk, Penanggulangan Kejahatan Korporasi Melalui Pendekatan Restoratif Suatu Terobosan Hukum, Sinar Grafika, Jakarta Timur, 2014, Hlm. 6
} 
Dayeuhkolot, saat ini telah tercemar, seperti yang telah dijelaskan dari hasil sampling yang dilakukan oleh organisasi lingkungan hidup Greenpeace di titik koordinat $6^{\circ} 58^{\prime} 31^{\prime} .7^{\prime} \mathrm{S}, 107^{\circ} 36^{\prime} 52.5$ 'E daerah Cisirung Dayeuhkolot. Dari hasil sampling tersebut dijelaskan, bahwa di lokasi tersebut terdapat temuan organik berbahaya jenis alkyphenol-BHT dan itu bersifat toksik bagi sistem reproduksi. ${ }^{8}$

Data kualitas air yang diukur kondisi Sungai Citarum sudah masuk ke tingkat pencemaran berat, dan sudah mencapai tahap kritis. Banyak parameter kunci yang sudah melebihi baku mutu, baik dari limbah organik hingga kandungan logam berat. Sekitar $40 \%$ limbah Sungai Citarum merupakan limbah organik, dan rumah tangga. Sisanya merupakan limbah kimia atau industri. Demikian pula halnya dengan dengan kondisi air tanah, pengambilan air tanah yang meningkat dari tahun ke tahun berimplikasi terhadap penurunan muka air tanah.

Berkaitan dengan kasus pencemaran Sungai Citarum, Pemerintah Provinsi Jawa Barat memberikan sanksi pada 14 perusahaan di Jawa Barat yang melakukan pencemaran limbah berbahaya

8 Ibid ke Derah Aliran Sungai (DAS) Citarum. Keseluruhan perusahaan tersebut antara lain bergerak dalam industri garmen, peternakan sapi, dan kertas serta peleburan besi. Lokasi perusahaan tersebut berada di Kota Cimahi (4 perusahaan), Kabupaten Bandung (1 perusahaan), KBB (2 perusahaan), Sumedang (2 perusahaan), Purwakarta (2 perusahaan), Kota Bekasi (1 perusahaan) dan Kabupaten Bekasi (2 perusahaan). Perusahaan di Sumedang dan Purwakarta mendapat sanksi pidana, sedangkan sisanya sanksi administratif.

Prinsip tanggung jawab dalam pengelolaan lingkungan hidup yang lebih proporsional adalah dengan metode tanggung jawab mutlak (strict liability) sebagaimana diatur dalam Pasal 88 Undang-Undang Nomor 32 Tahun 2009 tentang Perlindungan dan Pengelolaan Lingkungan Hidup. Ketentuan ini merupakan lex spesialis dalam gugatan tentang perbuatan melanggar hukum pada umumnya. Berkaitan dengan tindak pidana yang dilakukan oleh korporasi yang akibatnya telah menimbulkan dampak yang besar. Terdapat kesulitan dalam menjatuhkan pidana terhadap korporasi karena berkaitan dengan aturan hukum yang ada, yang berbeda dengan pidana untuk orang. 
Berdasarkan hal tersebut diatas, maka penulis dapat membuat identifikasi masalah dalam pembahasan ini yaitu:

1. Bagaimana fungsionalisasi penegakan hukum pidana terhadap korporasi yang melakukan pembuangan limbah B3 (bahan berbahaya dan beracun) di daerah aliran sungai Citarum dengan asas keadilan?

2. Bagaimana penegakan hukum pidana terhadap korporasi yang melakukan pembuangan limbah B3 (bahan berbahaya dan beracun) di daerah aliran sungai Citarum?

\section{B. HASIL DAN PEMBAHASAN}

1. Fungsionalisasi

Penegakan

Hukum Pidana Terhadap

Korporasi yang Melakukan

Pembuangan Limbah B3 (Bahan

Berbahaya Dan Beracun) Di

Daerah Aliran Sungai Citarum

\section{Dengan Asas Keadilan}

Fungsionalisasi penegakan hukum pidana dalam rangka pencegahan dan penanggulangan kejahatan umumnya serta kejahatan korporasi yang melakukan pembuangan limbah B3 di daerah aliran sungai Citarum dapat dilakukan beberapa tahap. Tahapan tersebut antara lain tahap formulasi, tahap aplikasi dan tahap eksekusi. Perlindungan dan pengelolaan lingkungan hidup harus mencerminkan keadilan secara proporsional bagi setiap warga Negara sesuai dengan asas keadilan. Asas keadilan ini ditujukan kepada bagi setiap warga Negara, baik lintas daerah, lintas generasi, maupun lintas gender.

Kegiatan-kegiatan ekonomi seperti pendirian sebuah pabrik, penetapan lokasi pembuangan limbah, pembangunan waduk, pengambilan bahan tambang dan hasil hutan yang dapat merugikan kepentingan suatu kelompok dalam masyarakat sehingga dapat menimbulkan sengketa dapat digolongkan ke dalam sengketa lingkungan hidup. Ancaman terhadap hak dan kepentingan sah dari suatu kelompok dalam masyarakat juga berarti dapat menggangu lingkungan sosial masyarakat yang bersangkutan. ${ }^{9}$

Pasal 57 Peraturan Pemerintah Nomor 38 Tahun 2011 tentang Sungai, menyatakan:

(1) Setiap orang yang akan melakukan kegiatan pada ruang sungai wajib memperoleh izin.

(2) Kegiatan sebagaimana dimaksud pada ayat (1) meliputi :

\footnotetext{
9 Takdir Rahmadi, Hukum Lingkungan Di Indonesia, Rajawali Press, Jakarta, 2013, Hlm. 267
} 
Gatot Satrio Utomo, Fungsionalisasi Hukum Pidana Terhadap Korporasi Yang Melakukan Pembuangan Limbah..

a. Pelaksanaan kontruksi pada ruang sungai;

b. Pelaksanaan kontruksi yang mengubah aliran dan/ atau aliran sungai;

c. Pemanfaatan bantaran dan sempadan sungai;

d. Pemanfaatan bekas sungai;

e. Pemanfaatan air sungai selain untuk kebutuhan pokok seharihari dan pertanian rakyat dalam sitem irigasi yang sudah ada;

f. Pemanfaatan sungai sebagai penyedia tenaga air;

g. Pemanfaatan sungai sebagai prasarana transportasi;

h. Pemanfaatan sungai di kawasan hutan;

i. Pembuangan air limbah ke sungai;

j. Pengambilan komoditas tambang di sungai; dan

k. Pemanfaatan sungai untuk perikanan menggunakan karamba atau jaring apung.

Ironisnya kondisi Sungai Citarum

saat ini dalam keadaan kritis akibat dari segala faktor yang ada, seperti pembuangan limbah kimia 280 ton/hari dari 1,500 industri, perambahan hutan yang mengakibatkan erosi $31,4 \%$ di kawasan hulu citarum, 400 ton limbah peternakan sapi yang di buang ke citarum, $500,000 \mathrm{~m}^{3} /$ tahun limbah rumah tangga/sampah masuk ke Sungai Citarum, pencemaran senyawa nitrogen dan fosfor dari pupuk pertanian. ${ }^{10}$ Selain itu,

\footnotetext{
10 Agung Budi Maryoto, Penanggulangan Pencemaran di Sungai Citarum Melalui
}

disebabkan juga oleh pencemaran biologis yang terjadi terutama di kota-kota (urbanisasi) karena ledakan penduduk yang menyebabkan sampah domestik meningkat, terjadinya perubahan tata guna tanah serta masalah irigasi.

Pasal 59 Peraturan Pemerintah Nomor 38 Tahun 2011 tentang Sungai, menyatakan pemegang izin kegiatan pada ruang sungai sebagaimana dimaksud dalam Pasal 57 wajib :

a. Melindungi dan memelihara kelangsungan fungsi sungai;

b. Melindungi dan mengamankan prasarana sungai;

c. Mencegah terjadinya pencemaran air sungai;

d. Menanggulangi dan memulihkan fungsi sungai dari pencemaran air sungai;

e. Mencegah gejolak sosial yang timbul berkaitan dengan kegiatan pada ruang sungai; dan

f. Memberikan akses terhadap pelaksanaan pemantauan, evaluasi, pengawasan dan pemeriksaan.

Selain dalam Peraturan Pemerintah Nomor 38 Tahun 2011 tentang Sungai, terdapat pula Peraturan Presiden Republik Indonesia Nomor 15 Tahun 2018 tentang Percepatan Pengendalian Pencemaran dan Kerusakan Daerah Aliran Sungai Citarum. Karena kondisi Citarum sudah sangat buruk, pembentukan Peraturan Presiden

Pengendalian dan Penindakan hukum, Polda Jabar, Bandung, 2017, Hlm. 4 
Gatot Satrio Utomo, Fungsionalisasi Hukum Pidana Terhadap Korporasi Yang Melakukan Pembuangan Limbah..

tersebut untuk melakukan percepatan Pengendalian Pencemaran dan Kerusakan DAS Citarum secara terpadu dibentuk Tim Pengendalian Pencemaran dan Kerusakan DAS Citarum, yang selanjutnya dalam Peraturan Presiden ini disebut Tim DAS Citarum.

Berdasarkan Pasal 60 Peraturan Pemerintah Nomor 38 Tahun 2011 tentang Sungai, maka sebaiknya putusan Majelis Hakim dalam kasus PT. Indo Buana Makmur adalah dikenai sanksi administrtif oleh pemberi izin sesuai dengan ketentuan perundang-undangan. Wajib melakukan pemulihan dan/ atau perbaikan atas kerusakan yang ditimbulkannya; dan/ atau kerugian pada masyarakat, wajib mengganti biaya kerugian yang dialami masyarakat.

Hukum juga sebagai alat rekayasa sosial, berperan merubah sikap sosial masyarakat, mengarahkan perilaku budaya setiap orang kepada paradigma pemanfaatan, pengelolaan sumber alam dengan pola efisien dengan meminimalisasi kerusakan, demikian juga terciptanya interaksi lingkungan yang bertujuan menyerasikan pembangunan dengan lingkungan. ${ }^{11}$

\footnotetext{
11 Siahaan N.H.T, Hukum Lingkungan, Pancuran
} Alam, Jakarta, 2009, Hlm. 37-38
Hukum pidan dikaitkan dengan keadilan prosedural, dimana keadilan prosedural berkaitan dengan hukum formil atau hukum acara yakni bagaimana menegakan atau menjalankan hukum materiil, sedangkan keadilan substantif berkaitan dengan hukum materiil. Dalam tataran filsafat dan teori dapat dikemukakan bahwa yang adil dalam norma belum tentu adil dalam pelaksanaannya. Oleh karena itu, pada tataran implementasi, keadilan prosedural dan keadilan substantif haruslah berjalan paralel.

Teori keadilan dalam fungsionalisasi hukum pidana terhadap korporasi, menurut Hampshire mengajukan teori keadilannya dengan mengacu pada sifat aturan hukum, sehingga melahirkan dua jenis keadilan, yaitu keadilan prosedural (procedural justice) dan keadilan subtantif (substantive justice) pada hakekatnya dapat dikategorikan ke dalam definisi keadilan distributif.

Masalah pidana dan tanggungjawab pidana pada delik atau tindak pidana lingkungan mempunyai cirri khas. Kekhususan itu terutama terletak pada tanggungjawab korporasi sebagai badan hukum yang memberikan legitimasi beroperasinya perusahaan atau badan 
usaha yang kemudian menimbulkan pencemaran lingkungan. Oleh karena itu, harus ada pihak yang bertanggungjawab atas terjadinya pencemaran lingkungan yang membawa kerugian masyarakat. ${ }^{12}$

Pembangunan berkelanjutan yang berwawasan lingkungan hidup berkaitan erat dengan pendayagunaan sumber daya alam sebagai suatu aset mewujudkan kesejahteraan rakyat. Dalam Undang-Undang Nomor 32 Tahun 2009 tentang Perlindungan dan Pengelolaan Lingkungan Hidup diperkenalkan suatu rumusan tentang pembangunan berkelanjutan yang berwawasan lingkungan hidup. Disebutkan dalam ketentuan berwawasan lingkungan hidup adalah upaya sadar dan terencana, yang memadukan lingkungan hidup, termasuk sumber daya ke dalam proses pembangunan untuk menjamin kemampuan, kesejahteraan dan mutu hidup generasi masa kini dan masa depan. Selanjutnya dalam undang-undang ini dibedakan antara "asas keberlanjutan" sebagai asas pengelolaan lingkungan hidup dan "pembangunan berwawasan lingkungan hidup" sebagai suatu sistem pembangunan.

\footnotetext{
12 Joni, Tindak Pidana Lingkungan Hidup, Pustaka Pelajar, Yogyakarta, 2016, Hlm. 87
}

\section{Penegakan Hukum Pidana}

Terhadap Korporasi yang

Melakukan Pembuangan Limbah

B3 (Bahan Berbahaya Dan

Beracun) Di Daerah Aliran

\section{Sungai Citarum}

\section{Hfjh}

Kebijakan yang integral antara upaya penal dan nonpenal, diharapkan "social defense planning" benar-benar dapat berhasil dan dengan demikian diharapkan pula tercapainya hakekat tujuan kebijakan sosial yang tertuang dalam rencana pembangunan nasional, yaitu "kualitas lingkungan hidup yang sehat dan bermakna". Mengingat upaya penanggulangan kejahatan melalui jalur non penal lebih bersifat tindakan pencegahan untuk terjadinya kejahatan, maka sasaran utamanya adalah menangani faktor-faktor kondusif penyebab terjadinya kejahatan. $^{13}$

Terkait penghukuman pelaku tindak pidana yang dilakukan oleh korporasi di bidang lingkungan hidup

\footnotetext{
${ }^{13}$ Barda Nawawi Arief, Bunga Rampai Kebijakan Hukum Pidana Perkembangan Penyusunan Konsep KUHP Baru, Kencana Prenada Media Group, Jakarta, 2008, Hlm. 40
} 
Gatot Satrio Utomo, Fungsionalisasi Hukum Pidana Terhadap Korporasi Yang Melakukan Pembuangan Limbah..

(korporasi dapat dipidana) maka serius terhadap lingkungan hidup pemidanaan terhadap korporasi diatur dalam Undang-Undang Nomor 32 Tahun 2009 tentang Perlindungan dan Pengelolaan Lingkungan Hidup khususnya Pasal 98 ayat (1) mengandung beberapa unsur yang harus dipenuhi dalam kerangka penerapan pemidanaan, yakni: Pertama, unsur barang siapa. Kedua, secara melawan

hukum. Ketiga, dengan sengaja. Keempat, melakukan perbuatan yang mengakibatkan dilampauinya baku mutu udara ambien, baku mutu air, baku mutu air laut atau kriteria baku kerusakan lingkungan hidup.

Pemerintah sebaiknya memberikan sanksi yang lebih tegas terhadap pelaku industri yang membuang air limbah tanpa menggunakan IPAL dan juga terhadap masyarakat yang membuang sampah ke sungai sehingga mencemari lingkungan dan mengakibatkan banjir.

Tindak pidana kerusakan lingkungan yang diakibatkan oleh kegiatan korporasi dalam Pasal 88 UUPPLH sudah mengatur secara tegas mengenai strict liability. Pasal 88 menyebutkan "setiap orang yang tindakannya, usahanya, dan/atau kegiatannya menggunakan B3, menghasilkan dan/atau mengelola limbah B3, dan/atau yang menimbulkan ancaman bertanggung jawab mutlak atas kerugian yang terjadi tanpa perlu pembuktian unsur kesalahan." Seperti telah dikemukakan sebelumnya bahwa dimaksud dengan strict liability adalah pembuat sudah dapat dipidana jika telah melakukan perbuatan sebagaimana dirumuskan dalam undangundang tanpa melihat bagaimana sikap batinnya, yaitu dapat diartikan pula sebagai "liability without fault" (pertanggungjawaban tanpa kesalahan). Pertanggungjawaban korporasi tindak pidana lingkungan harus memperhatikan hal berikut: ${ }^{14}$

a. Korporasi mencakup baik badan hukum (legal entity) maupun nonbadan hukum seperti organisasi dan sebagainya.

b. Korporasi dapat bersifat privat (private yuridical entity) dan dapat pula bersifat publik (public entity).

c. Apabila diidentifikasikan bahwa tindak pidana lingkungan dilakukan dalam bentuk organisasional, maka orang alamiah (managers, employess) dan korporasi dapat dipidana baik sendiri-sendiri maupun bersama-sama (bipunishment provision). 
d. Terdapat kesalahan manajemen dalam korporasi dan terjadi apa yang dinamakan breach of a statutory or regulatory provision.

e. Pertanggungjawaban badan hukum dilakukan terlepas dari apakah orangorang yang bertanggungjawab di dalam badan hukum tersebut berhasil diidentifikasi, dituntut dan dipidana.

f. Segala sanksi pidana dan tindakan pada dasarnya dapat dikenakan pada korporasi, kecuali pidana mati dan pidana penjara.

g. Penerapan sanksi pidana terhadap korporasi tidak menghapuskan kesalahan perorangan.

h. Pemidanaan terhadap korporasi hendaknya memerhatikan kedudukan korporasi untuk mengendalikan perusahaan, melalui kebijakan pengurus atau para pengurus (corporate executive officers) yang memiliki kekurangan untuk memutuskan (power of decision) dan keputusan tersebut telah diterima (accepted) oleh korporasi tersebut.

Pengaturan mengenai korporasi sebagai subjek hukum pidana, memiliki tiga model pertanggungjawaban pidana korporasi. Sebagaimana dikemukakan oleh Mardjono Reksodiputro dalam makalahnya mengemukakan

model pertanggungjawaban pidana korporasi sebagai berikut: ${ }^{15}$

a. Pengurus korporasi sebagai pembuat dan pengurus korporasi yang bertanggungjawab

b. Korporasi sebagai pembuat dan pengurus bertanggungjawab

c. Korporasi sebagai pembuat dan juga korporasi yang bertanggungjawab.

Pada model pertanggungjawaban pidana yang pertama maka pengurus korporasi yang bertindak sebagai pembuat dan pengurus korporasi juga yang bertanggungjawab. Kepada pengurus korporasi ini dibebankan kewajibankewajiban tertentu, meski kewajiban tersebut sebenarnya adalah kewajiban dari korporasi. Model pertanggungjawaban pidana korporasi yang pertama ini terdapat pada KUHP Indonesia yang berlaku saat ini. Jika melihat isi dari KUHP maka tidak akan ditemukan Pasal yang mengatur mengenai tindak pidana yang dilakukan oleh korporasi dan pertanggungjawaban pidana korporasi. Adapun mengenai delik yang berkaitan dengan korporasi, diatur

\footnotetext{
15 Mardjono Reksodiputro, Pertangung-jawaban Pidana Korporasi dalam Tindak Pidana Korporasi, FH UNDIP, Semarang, 1989, Hlm. 9.
} 
Gatot Satrio Utomo, Fungsionalisasi Hukum Pidana Terhadap Korporasi Yang Melakukan Pembuangan Limbah..

mengenai tindak pidana yang dilakukan oleh pengurus korporasi dan pertanggungjawaban pidananya.

Salah satu model pertanggungjawaban pidana yang pertama di dalam KUHP adalah Pasal 169 KUHP. Dalam ketentuan tersebut disebutkan mengenai turut serta dalam perkumpulan yang bertujuan melakukan kejahatan, perkumpulan lainnya yang dilarang oleh aturan, atau perkumpulan yang bertujuan melakukan pelanggaran, serta pemberatan pemidanaan bagi pengurus atau pendiri. Jika melihat ketentuan tersebut maka perbuatan pidana dan pertanggungjawaban lebih ditekankan kepada pengurus, bukan korporasinya. Pada beberapa Pasal lain yakni Pasal 398 dan Pasal 399 KUHP yang mengatur mengenai kepailitan suatu korporasi, juga membebankan pemidanaannya kepada pengurus. ${ }^{16}$

Pada model pertanggungjawaban pidana korporasi yang kedua maka korporasi sebagai subjek hukum sudah dikenal, sehingga korporasi sudah diakui mampu untuk melakukan perbuatan pidana, akan tetapi pertanggungjawabannya masih dibebankan kepada pengurus. Muladi dan Dwidja berpendapat bahwa model

\footnotetext{
${ }^{16}$ Ibid.
}

pertanggungjawaban pidana ini adalah pengurus ditunjuk sebagai yang bertanggungjawab atas apa yang dipandang dilakukan oleh korporasi, yakni apa yang dilakukan oleh alat perlengkapan korporasi menurut wewenang berdasarkan anggaran dasarnya. Lebih jelasnya, bahwa pengurus atau pemimpin dari korporasi bertanggungjawab atas perbuatan yang dilakukan oleh seseorang atau beberapa orang, yang dianggap sebagai tindakan dari korporasi, terlepas ia mengetahuinya atau tidak. Hal ini dikarenakan adanya kewajiban yang melekat pada diri pengurus atau pemimpin tersebut.

Pada model pertanggung- jawaban pidana korporasi yang ketiga ini maka kedudukan korporasi sebagai subjek hukum dapat dikatakan sudah diakui sepenuhnya. Hal ini dikarenakan korporasi sudah dianggap sebagai pembuat, dan terhadapnya juga dapat dimintakan pertanggungjawaban. Adapun peraturan yang pertama kali mengadopsi model pertanggung-jawaban pidana korporasi ini di Indonesia adalah Undang-Undang Penimbunan Barang pada tahun 1951. Akan tetapi model pertanggungjawaban pidana ini baru dikenal luas melalui Undang-Undang Tindak Pidana Ekonomi pada tahun 1955. 
Gatot Satrio Utomo, Fungsionalisasi Hukum Pidana Terhadap Korporasi Yang Melakukan Pembuangan Limbah..

Prinsip strict liability dalam Undang-Undang No. 32 Tahun 2009 tentang Perlindungan dan Pengelolaan Lingkungan Hidup. Secara harafiah istilah strict liability itu diterjemahkan menjadi, tanggung jawab secara tegas; tanggung jawab secara tepat; tanggung jawab secara teliti dan tanggung jawab secara keras.

Asas strict liability disebut pula dengan istilah absolut liability, yaitu prinsip tanggungjawab mutlak (no fault liability or liability without fault ) sebagai prinsip tanggungjawab tanpa keharusan untuk membuktikan adanya kesalahan dengan didasarkan alasan-alasan sebagai berikut:

a. Adalah sangat esensial untuk menjamin dipatuhinya peraturanperaturan penting tertentu yang diperlukan untuk kesejahteraan sosial.

b. Pembuktian adanya "mens rea" akan menjadi sangat sulit untuk pelanggaran-pelanggaran yang berhubungan dengan kesejahteraan sosial itu.

c. Tingginya tingkat bahaya sosial yang ditimbulkan oleh perbuatan yang bersangkutan.
Menurut common law, strict liability berlaku terhadap tiga macam delik:

a. Public nuisance (gangguan terhadap ketertiban umum, menghalangi jalan raya, mengeluarkan bau tidak enak).

b. Criminal libel (fitnah, pencemaran nama).

c. Contempt of court (pelanggaran tata tertib pengadilan).

d. Strict Liability sebagai pertanggungjawaban khusus dalam hukum

Lingkungan ilmu hukum mengenal dua jenis tanggung gugat, yaitu tanggung gugat berdasarkan kesalahan (liability based on fault) dan tanggung gugat tidak berdasarkan kesalahan (liability without fault) atau yang juga disebut strict liability. Selain tetap menganut tanggung gugat berdasarkan kesalahan, UUPPLH juga memberlakukan tanggung gugat tanpa kesalahan (strict liability) yaitu untuk kegiatan-kegiatan yang "menggunakan bahan-bahan berbahaya dan beracun atau menghasilkan dan/atau mengelola limbah bahan berbahaya dan beracun dan/atau yang menimbulkan ancaman serius terhadap lingkungan hidup."

Penegakan hukum administrasi merupakan upaya pencegahan dengan 
penerapan sistem perizinan dan tindakantindakan sebelum terjadinya pencemaran dan/atau kerusakan lingkungan hidup. Sanksi administrasai tersebut diantaranya:

a. Teguran tertulis (Pasal 76 ayat (2a) UUPPLH)

b. Paksaan pemerintah (Pasal 76 ayat (2b) dan Pasal 80 UUPPLH)

c. Pembekuan ijin (Pasal 76 ayat (2c) UUPPLH)

d. Pencabutan ijin (Pasal 7 ayat (2d) dan 79 UUPPLH)

e. Denda administratif (Pasal 81 UUPPLH)

f. Serta sanksi lain yang diatur dalam peraturan turunan maupun peraturan tingkat daerah.

Penegakan hukum lingkungan merupakan upaya untuk mencapai ketaatan penuh terhadap peraturan dan persyaratan ketentuan hukum melalui pengawasan dan penerapan dari sanksi administrasi, keperdataan dan kepidanaan yang dapat dikenakan terhadap para pelanggarnya dalam upaya mencapai harmonisasi lingkungan yang dicitakan. ${ }^{17}$

\section{PENUTUP}

\section{Simpulan}

\footnotetext{
17 Teguh Sulistia, Aria zurnetti, Hukum Pidana Horizon Baru Pasca Reformasi, PT. Raja Grafindo Persada, Jakarta, 2012, Hlm. 164
}

1. Fungsionalisasi penegakan hukum pidana terhadap korporasi yang melakukan pembuangan limbah b3 (bahan berbahaya dan beracun) di daerah aliran sungai citarum dengan asas keadilan dapat dilakukan melalui beberapa tahap, yaitu tahap formulasi, tahap aplikasi dan tahap eksekusi. Fungsionalisasi hukum pidana sebagai bagian dari upaya penegakan hukum tidak bisa dilepaskan dari sistem hukum secara keseluruhan yang meliputi substansi hukum, struktur hukum, dan budaya hukum. Apabila ketiga subsistem hukum tersebut berjalan dengan baik, maka diharapkan fungsionalisasi penegakan hukum pidana bisa berperan dalam kebijakan penanggulangan kejahatan secara luas, untuk mencapai keadilan.

2. Penegakan hukum pidana terhadap korporasi yang melakukan pembuangan limbah B3 (bahan berbahaya dan beracun) di daerah aliran sungai Citarum, yaitu dengan menggunakan asas Primum Remedium, yang berarti, bahwa hukum pidana digunakan sebagai sarana utama dalam pemidanaan terhadap korporasi. Hal ini 
disebabkan mekanisme penegakan hukum lainnnya yang lebih ringan seperti teguran/surat peringatan dari instansi terkait tidak berdaya guna atau tidak dipandang oleh para pelaku tindak pidana lingkungan hidup khususnya pengelolaan limbah B3.

\section{Saran}

1. Kebijakan penegakan hukum lingkungan tidak bisa dilepaskan dari politik hukum pemerintah, khususnya politik hukum pidana. Oleh karena itu fungsionalisasi hukum pidana dalam bidang lingkungan hidup harus mendapat dukungan politik, mengingat kejahatan lingkungan hidup mempunyai pengaruh yang sangat besar terhadap aspek-aspek kehidupan masyarakat.

2. Perlu adanya undang-undang khusus yang mengatur mengenai pertanggungjawaban korporasi yang melakukan tindak pidana, mengingat selama ini pertanggungjawaban korporasi tersebut diatur dalam beberapa peraturan perundangundangan. Langkah-langkah yang perlu diperhatikan berkaitan dengan pembuangan limbah B3 dapat dilakukan melalui beberapa upaya, di antaranya industri segera berkomitmen menghentikan pembuangan bahan kimia berbahaya dan beracun melalui produksi bersih.

\section{DAFTAR PUSTAKA}

Agung Budi Maryoto, Penanggulangan Pencemaran di Sungai Citarum Melalui Pengendalian dan Penindakan hukum, Polda Jabar, Bandung, 2017

Barda Nawawi Arief, Beberapa Aspek Kebijakan Penegakan Hukum Pidana dan Pengembangan Hukum Pidana, PT. Citra Aditya Bakti, Bandung, 1998.

Kebijakan Hukuma Rampai Perkembangan Penyusunan Konsep KUHP Baru, Kencana Prenada Media Group, Jakarta, 2008

Joni, Tindak Pidana Lingkungan Hidup, Pustaka Pelajar, Yogyakarta, 2016.

Mardjono Reksodiputro, Pertangungjawaban Pidana Korporasi dalam Tindak Pidana Korporasi, $\quad$ FH UNDIP, Semarang, 1989.

Muhammad Erwin, Hukum Lingkungan Dalam Sistem Perlindungan dan Pengelolaan Lingkungan Hidup di Indonesia, PT. Refika Aditama, Bandung, 2015.

Muladi dan Barda Nawawi Arif, Teoriteori dan Kebijakan Pidana, Alumni, Bandung, 2005.

Rufinus Hotmaulana Hutauruk, Penanggulangan Kejahatan Korporasi Melalui Pendekatan Restoratif Suatu Terobosan Hukum, Sinar Grafika, Jakarta Timur, 2014 
Gatot Satrio Utomo, Fungsionalisasi Hukum Pidana Terhadap Korporasi Yang Melakukan Pembuangan Limbah..

Satjipto Rahardjo, Ilmu Hukum, PT. Citra Aditya Bakti, Bandung, 2005.

Siahaan N.H.T, Hukum Lingkungan, Pancuran Alam, Jakarta, 2009.

Sudarto, Kapita Selekta Hukum Pidana, Alumni, Bandung, 1985.

Sudikno Mertokusumo, Mengenal Hukum (Suatu Pengantar), Liberty, Yogyakarta, 1999.

Takdir Rahmadi, Hukum Lingkungan Di Indonesia, Rajawali Press, Jakarta, 2013.

Teguh Sulistia, Aria zurnetti, Hukum Pidana Horizon Baru Pasca Reformasi, PT. Raja Grafindo Persada, Jakarta, 2012. 